Review

\title{
Non-invasive In-Vivo Imaging of Stem Cells after Transplantation in Cardiovascular Tissue
}

\author{
Anders Bruun Mathiasen, Jens Kastrup ${ }^{凶}$ \\ Cardiac Stem Cell Laboratory and Cardiac Catheterization Laboratory 2014, The Heart Centre, Rigshospitalet, Copenhagen University \\ Hospital, Copenhagen, Denmark.
}

\begin{abstract}
$\square$ Corresponding author: Anders Bruun Mathiasen MD. Cardiac Catheterization Laboratory 2014. The Heart Centre,Rigshospitalet, Copenhagen University Hospital Blegdamsvej 9, DK-2100 Copenhagen, Denmark.E-mail: abbe@dadlnet.dkTelephone: +45 35450673Fax: +45 35452705 .
\end{abstract}

() Ivyspring International Publisher. This is an open-access article distributed under the terms of the Creative Commons License (http://creativecommons.org/ licenses/by-nc-nd/3.0/). Reproduction is permitted for personal, noncommercial use, provided that the article is in whole, unmodified, and properly cited.

Received: 2012.12.31; Accepted: 2013.03.03; Published: 2013.07.20

\begin{abstract}
Stem cell therapy for degenerative diseases, including ischemic heart disease is now a clinical reality. In the search for the optimal cell type for each patient category, many different stem cell subpopulations have been used. In addition, different cell processing procedures and delivery methods have been utilized. Moreover, choices of endpoints have varied between studies. Diverging results have been reported from clinical experiences, with some studies demonstrating promising results with improved cardiac function and reduced mortality and clinical symptoms, and others have seen no improvements. To better understand the underlying mechanisms of these results, a reverse translation from bedside to bench has been opened. Non-invasive cell tracking after implantation has a pivotal role in this translation. Imaging based methods can help elucidate important issues such as retention, migration and efficacy of the transplanted cells. Great effort is being made in finding new and better imaging techniques for different imaging modalities, and much have already been learned. But there are still many unanswered questions. In this review, we give an overview of the imaging modalities used for cell tracking and summarize the latest advances within the field.
\end{abstract}

Key words: Stem cells, In-vivo imaging, radionuclides, super paramagnetic iron oxide, reporter genes, cardiovascular, heart.

\section{Introduction}

Coronary artery disease (CAD) is the most common cause of death in western countries $[1,2]$. Despite advances in treatment of CAD with stabilizing medication and mechanical revascularization, a large number of patients cannot be treated successfully and suffer from refractory angina and post infarction heart failure.

Stem cell therapy with the potential to regenerate damaged tissue is an emerging treatment modality in many diseases including CAD [3]. This field has been dominated by a quick translation from bench to bedside, where most early clinical trials have had a pragmatic design with intracoronary infusion of autologous bone marrow derived mononuclear cells (MNCs). The cell processing procedures and methods of implantation often vary between research groups, and choice of endpoint assessment in these clinical trials are often determined by local accessibility and expertise rather than by scientific rationale which has led to a number of clinical trials with diverging results.

This has opened for a reverse translation back to bench to clarify some of the unknown factors. A key question is to assess the migration and retention of 
these transplanted stem cells at the site of delivery. Moreover, there is a need to develop non-invasive technologies to assess their in vivo efficacy.

Development of methods for monitoring stem cell grafts non-invasively, with sufficiently high sensitivity and specificity to identify and map the fate of transplanted cells has a pivotal role in this translation. The ideal imaging method should permit longitudinal tracking of implanted cells for months to years allowing long-term follow-up of tissue function and donor survival. Also, the imaging technique should provide high spatial resolution and the capability of tracking cells without affecting the cells or the target organ. It is therefore important that the chosen labels or markers remain within the viable cells, and is quickly cleared from the tissue upon cell death. No single imaging modality currently meets all of the demands, but various modalities can be used for cell imaging. The most effective imaging strategy must be determined in each case considering the need for high spatial resolution, sensitivity, or time of follow up.

In this review, we will summarize the latest advances within the field of molecular imaging of cardiovascular stem cell transplantation and describe various cell labeling and imaging techniques.

\section{Cardiovascular cell tracking with radio- nuclides}

Imaging of radionuclide labeled cells using single-photon emission computed tomography (SPECT) or Positron emission tomography (PET) have been used for cell tracking in both animal and human clinical cardiovascular studies. Cell tracking using radioisotopes provides a highly sensitive spatial visualization of cells in vivo. However, PET and particularly SPECT have inferior spatial resolution compared with magnetic resonance imaging (MRI). Moreover, the radioisotopes have relative short half-lives and cells can only be visualized as long as the radioactivity is still detectable. This has limited the use of these methods for investigating the short-term fate of transplanted cells.

\section{Radioactive contrast agents for stem cell tracking}

A number of radionuclides can theoretically be used for stem cell labeling, and the most commonly used are ${ }^{18} \mathrm{~F}$ - fluorodeoxyglucose $\left({ }^{18} \mathrm{~F}-\mathrm{FDG}\right)$ for PET imaging and ${ }^{111}$ In-oxine, ${ }^{111}$ In-tropolone and 99mTc-hexamethylpropylenamineoxime (99mTcHMPAO) for SPECT imaging. A persistent limitation for SPECT imaging is that in order to generate useful images within a reasonable timeframe, the administration of relatively large doses of radioactivity are required. This poses the concern of inherent radiation damage to the cells. PET has a better spatial and temporal resolution than SPECT, which in theory makes it better suited for stem cell tracking than SPECT. However the half-life of ${ }^{18} \mathrm{~F}$ is only 110 minutes compared to 2.8 days for ${ }^{111}$ In and 6 hours for $99 \mathrm{mTc}$. Thus, until isotopes with longer half-lives are introduced for clinical use, only the immediate fate of transplanted stem cells can be investigated.

\section{Cardiovascular animal cell tracking studies using radionuclides}

Tracking of radionuclide labeled cells have been utilized in both animal and human studies (see Table 1).

In a rat study, human endothelial progenitor cells (EPCs) labeled with ${ }^{111}$ In-oxine, were injected both intravenously and into the left ventricle of the heart after myocardial infarction (MI) [4]. After 96 hours the radioactivity in the heart was only $1-2 \%$ of the total with intravenous injection, this increased to $3-5 \%$ after ventricular injection. Cardiac retention was higher in MI rats than in sham operated rats. Postmortem Immunostaining of cryosections from the infarcted hearts confirmed that EPCs homed predominantly to the infarct border zone. Moreover, the labeling procedure did not affect viability, proliferation, or migratory capacity. The same group did another rat study in which human hematopoietic stem cells (HSCs) labeled with ${ }^{111}$ In-oxine were injected into the left ventricle after MI [5]. Again only a small number amount $(1 \%)$ of radioactivity was from the heart after 96 hours. Interestingly this study showed impairment of cell proliferation and differentiation induced by ${ }^{111}$ In-oxine.

Tran et al. did a study on rats with autologous mesenchymal stromal cells (MSCs) labeled with ${ }^{111}$ In-oxine were injected intramyocardially 4 weeks post MI [6]. In an initial in-vitro experiment the spontaneous leaking rate of ${ }^{111}$ In-oxine from labeled MSCs was measured to $28 \%$ per hour during the first 2 hours and hereafter decreased rapidly. As a consequence of this, only $44 \%$ of ${ }^{111}$ In-oxine was retained within the MSCs after 2 hours, 27\% after 1 day and $20 \%$ after 7 days. Radioactivity in the hearts after 2 hours was $27 \%, 17 \%$ at day 1 and $12 \%$ at day 7 . Once these values were corrected for the radioactive leakage measured at the same time-points, a mean constant value of $60 \%$ of injected MSCs was estimated to be retained within the hearts over a period of 7 days. In another rat study, allogeneic cardiac derived stem cells (CDCs) labeled with ${ }^{18} \mathrm{~F}-\mathrm{FDG}$ were injected intramyocardially into the infarct border zone after MI [7]. After 1 hour $18 \%$ of radioactivity was retained in 
the heart. Slowing the heart rate with adenosine doubled the CDC retention to $35 \%$. ${ }^{18} \mathrm{~F}-\mathrm{FDG}$ labeling had no effect on cell viability and proliferation for up to 7 days after labeling.

Mitchell et al. labeled EPCs with ${ }^{111}$ In-tropolone and injected the cells in a canine MI model [8]. After 15 days of follow-up it was demonstrated that cell retention following endocardial and epicardial injection were similar (54-57\%). This finding had clinical impact since epicardial injections usually requires thoracotomy in patients, whereas endocardial injections can be performed via a minimal invasive injection catheter. Using the same cell type, injection method and canine model Sabondjian et al. recently demonstrated that hybrid SPECT/perfusion computed tomography (CT) of ${ }^{111}$ In-tropolone labeled cells can localize the cells in relation to the infarcted myocardium after intramyocardial injection [9].

A swine study by Hou et al. compared intramyocardial injection, intracoronary infusion and interstitial retrograde coronary venous infusion of ${ }^{111}$ In-oxine labeled peripheral blood MNCs [10]. After 6 days, significantly more cells were retained after intramyocardial injection $(11 \%)$ compared with intracoronary $(2.6 \%)$ and interstitial retrograde coronary venous delivery (3.2\%).

Table I. Cardiovascular animal cell tracking studies with radionuclides.

\begin{tabular}{|c|c|c|c|c|c|}
\hline Study & $\begin{array}{l}\text { Species } \\
(\mathrm{n})\end{array}$ & Cell type & Agent & Delivery & Results \\
\hline \multicolumn{6}{|c|}{ Small animals } \\
\hline $\begin{array}{l}\text { Aicher et } \\
\text { al. } \\
2003[4]\end{array}$ & $\begin{array}{l}\text { Rats } \\
(16)\end{array}$ & $\begin{array}{l}\text { Xenogeneic } \\
\text { EPC }\end{array}$ & $\begin{array}{l}{ }^{111} \text { In-oxine } \\
\text { (SPECT) }\end{array}$ & $\begin{array}{l}\text { Intravenous } \\
\text { Into the left } \\
\text { ventricle }\end{array}$ & $\begin{array}{l}\text { After } 96 \text { hours the radioactivity in the heart was only } 1-2 \% \text { of the total } \\
\text { with intravenous injection, this increased to } 3-5 \% \text { after ventricular injec- } \\
\text { tion. Cardiac retention was higher in MI rats than in sham operated rats. } \\
\text { The labeling procedure did not affect viability, proliferation, or migratory } \\
\text { capacity. } \\
\text { Immunostaining of cryosections from infarcted hearts confirmed that } \\
\text { EPCs homed predominantly to the infarct border zone. }\end{array}$ \\
\hline $\begin{array}{l}\text { Brenner et } \\
\text { al. } \\
2004[5]\end{array}$ & $\begin{array}{l}\text { Rats } \\
(8)\end{array}$ & $\begin{array}{l}\text { Xenogeneic } \\
\text { HSC }\end{array}$ & $\begin{array}{l}{ }^{111} \text { In-oxine } \\
(\mathrm{SPECT})\end{array}$ & $\begin{array}{l}\text { Into the left } \\
\text { ventricle }\end{array}$ & $\begin{array}{l}\text { At } 96 \text { hours only } 1 \% \text { of total radioactivity was detected in the heart. } \\
\text { 111 In-oxine induced impairment of cell proliferation and differentiation. }\end{array}$ \\
\hline $\begin{array}{l}\text { Tran et al. } \\
2006[6]\end{array}$ & $\begin{array}{l}\text { Rats } \\
(12)\end{array}$ & $\begin{array}{l}\text { Autologous } \\
\text { MSC }\end{array}$ & $\begin{array}{l}{ }^{111} \text { In-oxine } \\
\text { (SPECT) }\end{array}$ & $\begin{array}{l}\text { Direct Intra- } \\
\text { myocardial into } \\
\text { infarct lesion }\end{array}$ & $\begin{array}{l}60 \% \text { of injected MSCs were estimated to be retained within the hearts } \\
\text { over a period of } 7 \text { days after correcting for the spontaneous leaking rate of } \\
{ }^{111} \text { In-oxine from labeled MSCs. } \\
\text { Cell proliferation was not impaired by }{ }^{111} \text { In-oxine }\end{array}$ \\
\hline $\begin{array}{l}\text { Terrovitis } \\
\text { et al. } \\
2009[7]\end{array}$ & $\begin{array}{l}\text { Rats } \\
(85)\end{array}$ & $\begin{array}{l}\text { Allogeneic } \\
\text { CDC }\end{array}$ & $\begin{array}{l}{ }^{18} \mathrm{~F}-\mathrm{FDG} \\
(\mathrm{PET})\end{array}$ & $\begin{array}{l}\text { Direct Intra- } \\
\text { myocardial into } \\
\text { infarct border } \\
\text { zone }\end{array}$ & $\begin{array}{l}\text { After } 1 \text { hour } 18 \% \text { of radioactivity was retained in the heart. } \\
\text { Adenosine slowed the ventricular rate and doubled CDC retention } \\
\text { labeling had no effect on cell viability and proliferation for up to } 7 \text { days }\end{array}$ \\
\hline \multicolumn{6}{|c|}{ Larger animals } \\
\hline $\begin{array}{l}\text { Mitchell et } \\
\text { al. } \\
2010[8]\end{array}$ & $\begin{array}{l}\text { Canine } \\
(7)\end{array}$ & $\begin{array}{l}\text { Autologous } \\
\text { EPC }\end{array}$ & $\begin{array}{l}{ }^{111} \text { In-tropolone } \\
\text { (SPECT) }\end{array}$ & $\begin{array}{l}\text { Percutaneous } \\
\text { Intramyocardial } \\
\text { into infarct } \\
\text { border zone }\end{array}$ & $\begin{array}{l}\text { After } 15 \text { days of follow-up cell retention following endocardial and epi- } \\
\text { cardial injection were similar (54-57\%). }\end{array}$ \\
\hline $\begin{array}{l}\text { Sabondjian } \\
\text { et al. } \\
2012[9]\end{array}$ & $\begin{array}{l}\text { Canine } \\
(10)\end{array}$ & $\begin{array}{l}\text { Autologous } \\
\text { EPC }\end{array}$ & $\begin{array}{l}{ }^{111} \text { In-tropolone } \\
\text { (SPECT) }\end{array}$ & $\begin{array}{l}\text { Direct and per- } \\
\text { cutaneous In- } \\
\text { tramyocardial } \\
\text { into infarct } \\
\text { border zone }\end{array}$ & $\begin{array}{l}\text { Hybrid SPECT/perfusion CT of }{ }^{111} \text { In labeled cells can localize the cells in } \\
\text { relation to the infarcted myocardium after intramyocardial injection. }\end{array}$ \\
\hline $\begin{array}{l}\text { Hou et al. } \\
{[10]}\end{array}$ & $\begin{array}{l}\text { Swine } \\
(16)\end{array}$ & $\begin{array}{l}\text { Autologous } \\
\text { MNC }\end{array}$ & $\begin{array}{l}\text { 111In-oxine } \\
\text { (SPECT) }\end{array}$ & $\begin{array}{l}\text { intramyocardial, } \\
\text { intracoronary } \\
\text { and interstitial } \\
\text { retrograde cor- } \\
\text { onary venous } \\
\text { infusion }\end{array}$ & $\begin{array}{l}\text { Within the myocardium, significantly more cells were retained after } \\
\text { intramyocardial injection }(11 \%) \text { compared with intracoronary }(2.6 \%) \text { and } \\
\text { interstitial retrograde coronary venous delivery }(3.2 \%) \text {. }\end{array}$ \\
\hline
\end{tabular}

EPC: endothelial progenitor cells; SPECT: single-photon emission computed tomography; MI: myocardial infarction; HSC: hematopoietic stem cells; MSC: mesenchymal stromal cells; CDC cardiac derived stem cells; ${ }^{18} \mathrm{~F}-\mathrm{FDG}$ : ${ }^{8} \mathrm{~F}$ - fluorodeoxyglucose; PET: Positron emission tomography; MNC: mononuclear cells; CT: computed tomography. 


\section{Clinical cardiovascular cell tracking studies using radionuclides}

Several clinical human trials have explored tracking of radionuclide labeled progenitor cells (see Table 2).

Hofmann et al. performed either intravenous $(n=3)$ or intracoronary infusion $(n=3)$ of ${ }^{18}$ F-FDG labeled autologous bone-marrow MNCs, in addition to intracoronary infusion $(n=3)$ of ${ }^{18}$ F-FDG labeled CD34+ cells in patients with ST-elevation myocardial infarction (STEMI) [11]. PET scan after 1 hour revealed that after intracoronary transfer $1.3 \%$ to $2.6 \%$ of radioactivity was detected in the myocardium. After intravenous transfer, only background activity was detected in the myocardium. MNCs engrafted in both the infarct center and the border zone. Homing of CD34+ cells was more pronounced in the border zone. Another clinical study on 6 STEMI patients also used intracoronary infusion of ${ }^{18} \mathrm{~F}-\mathrm{FDG}$ labeled CD34+ cells [12]. After 1 hour PET scan showed 5.5\% of total radioactivity in the myocardium. Homing was predominantly in the border zone of the infarct area.

Eight patients with chronic ischemic heart disease underwent intracoronary infusion of
99mTc-HMPAO labeled Autologous CD133+CD34Cells [13]. SPECT imaging after 1 and 24 hours showed $9.2 \pm 3.6 \%$ and $6.8 \pm 2.4 \%$ of the total infused radioactivity in the infarcted area of the heart respectively.

Kang et al. recruited 20 STEMI patients in a study and these underwent either intravenous $(n=3)$ or intracoronary infusion $(\mathrm{n}=17)$ of ${ }^{18} \mathrm{~F}-\mathrm{FDG}$ labeled autologous hematopoietic stem cells [14]. 2 hours after intracoronary infusion, PET/CT revealed that $1.5 \%$ (range: $0.2 \%-3.3 \%$ ) of the infused radioactivity accumulated at the infarcted myocardium. Intravenous injection of stem cells showed no myocardial activity. In another study, 10 patients with acute and chronic $\mathrm{MI}$ received intracoronary infusion of ${ }^{99 \mathrm{~m} T \mathrm{~T}-\mathrm{HMPAO}}$ labeled autologous MNCs [15]. In the SPECT imaging done 2 hours after intracoronary infusion myocardial activity was observed in all patients with acute (range $1.31-5.10 \%)$ and in all but one patient with chronic infarction (range 1.10-3.0\%). At 20 hours, myocardial engraftment was noted only in three patients with acute myocardial infarction, whereas no myocardial activity was noted in any patient with chronic infarction.

Table 2. Cardiovascular clinical human cell tracking studies with radionuclides.

\begin{tabular}{|c|c|c|c|c|c|}
\hline Study & Patient (n) & Cell type & Agent & Delivery & Results \\
\hline $\begin{array}{l}\text { Hofmann et al. } \\
2005 \text { [11] }\end{array}$ & 9) & $\begin{array}{l}\text { Autologous } \\
\text { MNC and } \\
\text { CD34+ Cells }\end{array}$ & $\begin{array}{l}{ }^{18} \mathrm{~F}-\mathrm{FDG} \\
(\mathrm{PET})\end{array}$ & $\begin{array}{l}\text { Intravenous } \\
\text { / Intracoro- } \\
\text { nary }\end{array}$ & $\begin{array}{l}1 \text { hour after intracoronary transfer } 1.3 \% \text { to } 2.6 \% \text { of total radioactiv- } \\
\text { ity was detected in the myocardium. } \\
1 \text { hour after intravenous transfer, only background activity was } \\
\text { detected in the myocardium. } \\
\text { MNCs engrafted in the infarct center and border zone. Homing of } \\
\text { CD34+ cells was more pronounced in the border zone. }\end{array}$ \\
\hline $\begin{array}{l}\text { Blocklet et al. } \\
2006 \text { [12] }\end{array}$ & STEMI (6) & $\begin{array}{l}\text { Autologous } \\
\text { CD34+ Cells }\end{array}$ & $\begin{array}{l}{ }^{18} \mathrm{~F}-\mathrm{FDG} \\
(\mathrm{PET})\end{array}$ & $\begin{array}{l}\text { racoro- } \\
\text { ry }\end{array}$ & $\begin{array}{l}1 \text { hour after intracoronary transfer } 5.5 \% \text { of total radioactivity was } \\
\text { detected in the infarcted myocardium. } \\
\text { Homing was predominantly in the border zone of the infarct area. }\end{array}$ \\
\hline $\begin{array}{l}\text { Goussetis et al. } \\
2006 \text { [13] }\end{array}$ & $\begin{array}{l}\text { Chronic } \\
\text { IHD (8) }\end{array}$ & $\begin{array}{l}\text { Autologous } \\
\text { CD133+CD34- } \\
\text { Cells }\end{array}$ & $\begin{array}{l}\text { 99mTc-HMP } \\
\text { AO } \\
(\text { SPECT) }\end{array}$ & $\begin{array}{l}\text { Intracoro- } \\
\text { nary }\end{array}$ & $\begin{array}{l}1 \text { hour after intracoronary transfer of } 9.2 \% \text { of total infused radioac- } \\
\text { tivity was located in the infarcted area of the heart. } \\
\text { After } 24 \text { hours } 6.8 \% \text { of total infused radioactivity was located in the } \\
\text { infarcted area of the heart. }\end{array}$ \\
\hline $\begin{array}{l}\text { Kang et al. } \\
2006 \text { [14] }\end{array}$ & $\begin{array}{l}\text { STEMI } \\
(20)\end{array}$ & $\begin{array}{l}\text { Autologous } \\
\text { HSC }\end{array}$ & $\begin{array}{l}\text { 18F-FDG } \\
(\mathrm{PET} / \mathrm{CT})\end{array}$ & $\begin{array}{l}\text { Intravenous } \\
\text { / Intracoro- } \\
\text { nary }\end{array}$ & $\begin{array}{l}2 \text { hours after intracoronary infusion, } 1.5 \% \text { of infused radioactivity } \\
\text { accumulated at the infarcted myocardium } \\
\text { Intravenous injection of stem cells showed no myocardial activity. }\end{array}$ \\
\hline $\begin{array}{l}\text { Penicka et al. } \\
2007 \text { [15] }\end{array}$ & $\begin{array}{l}\text { STEMI } \\
\text { and } \\
\text { chronic } \\
\text { IHD (10) }\end{array}$ & $\begin{array}{l}\text { Autologous } \\
\text { MNC }\end{array}$ & $\begin{array}{l}\text { 99mTc-HMP } \\
\text { AO } \\
\text { (SPECT) }\end{array}$ & $\begin{array}{l}\text { Intracoro- } \\
\text { nary }\end{array}$ & $\begin{array}{l}2 \text { hours after intracoronary infusion myocardial activity was ob- } \\
\text { served in all acute patients (range } 1.31-5.10 \% \text { ) and in all but one } \\
\text { chronic patient (range } 1.10-3.0 \% \text { ). At } 20 \text { hours, myocardial en- } \\
\text { graftment was noted only in three acute patients and none with } \\
\text { chronic infarction. }\end{array}$ \\
\hline $\begin{array}{l}\text { Schächinger et } \\
\text { al. } \\
2008 \text { [16] }\end{array}$ & $\begin{array}{l}\text { STEMI } \\
\text { and } \\
\text { chronic } \\
\text { IHD (19) }\end{array}$ & $\begin{array}{l}\text { Autologous } \\
\mathrm{CPC}\end{array}$ & $\begin{array}{l}{ }^{111} \text { In-oxine } \\
\text { (SPECT) }\end{array}$ & $\begin{array}{l}\text { Intracoro- } \\
\text { nary infusion }\end{array}$ & $\begin{array}{l}\text { One hour after application of CPCs } 6.9 \% \text { of total radioactivity was } \\
\text { detected in the heart, which declined to } 2 \% \text { after } 3 \text { to } 4 \text { days. Av- } \\
\text { erage activity within the first } 24 \text { hours was highest among patients } \\
\text { with acute myocardial infarction and progressively decreased in } \\
\text { patients with older infarctions. }\end{array}$ \\
\hline
\end{tabular}

STEMI: ST-elevation myocardial infarction; MNC: mononuclear cells; $18 \mathrm{~F}-\mathrm{FDG}$ : 18F- fluorodeoxyglucose; PET: Positron emission tomography; IHD: ischemic heart disease; ${ }^{99 m T c}$-HMPAO: $99 \mathrm{mTc}$-hexamethylpropylenamineoxime; HSC: hematopoietic stem cells; CT: computed tomography; CPC: circulating progenitor cells. 
${ }^{111}$ In-oxine labeled progenitor cells were infused into the lesion supplying coronary artery in 20 patients after acute or chronic MI [16]. One hour after the infusion of progenitor cells, a mean of $6.9 \pm 4.7 \%$ of the total radioactivity was detected in the heart. Radioactivity declined to $2 \pm 1 \%$ after 3 to 4 days, indicating homing of progenitor cells to the myocardium. The average radioactivity within the first 24 hours was highest among patients with acute MI and progressively decreased in patients with older infarctions.

\section{Cardiovascular cell tracking with MRI}

A number of studies have shown the feasibility of longitudinal non-invasive monitoring of transplanted cells in pre-clinical models using MRI. This approach could potentially be translated into clinical practice for evaluating stem cell survival and for monitoring therapeutic intervention during tissue rejection. MRI is well suited for stem cell tracking because it can pro-vide both whole-body and detailed information on host organs with near microscopic anatomical resolution and excellent soft-tissue contrast.

\section{Intracellular MRI contrast agents}

For stem cells to be visualized and tracked by MRI, they need to be tagged with a contrast agent so that they are 'MR visible'. MRI contrast agents either alter the $\mathrm{T} 1$ and/or $\mathrm{T} 2$ relaxation time, making the local tissue hyper- or hypo-intense respectively. At present there are two types of MR contrast agent used clinically. These are paramagnetic gadolinium-analogues ( $\mathrm{Gd}^{3+}$-DTPA) or super-paramagnetic iron-oxide nanoparticles. Due to their biocompatibility and strong effect on T2 relaxation time, iron-oxide nanoparticles have been the MRI contrast agent of choice for cell labeling.

Super-paramagnetic reagents consist of an iron oxide core, typically $4-10 \mathrm{~nm}$ in diameter, where several thousands of iron atoms are present. A biocompatible polymer surrounds the core to provide steric and/or electrostatic stabilization. There are two types of super-paramagnetic contrast agents, super-paramagnetic iron oxide (SPIO) and ultra-small super-paramagnetic iron oxide (USPIO). The difference between the two is that the SPIOs consist of several magnetic cores surrounded by a polymer matrix whereas USPIOs are individual cores surrounded by a polymer. Super-paramagnetic contrast agents provide predominantly a $\mathrm{T} 2$ effect, but smaller particles have shown to possess additional T1 properties [17]. A new class of USPIO has been produced known as cross-linked iron oxide (CLIO), whereby the dextran coat of the USPIO is cross-linked in the presence of epichlorohydrin, and then subjected to amination in the presence of ammonia to produce amine-terminated nanoparticles suitable for conjugation [18].

\section{Internalization of Intracellular MRI contrast agents}

The contrast agents used in clinical settings were not designed for cellular internalization. To cross the cell membrane, contrast agents must either be used in conjunction with a transfection agent such as poly-L-lysine $[19,20]$ or protamine sulfate [21], or conjugated to a biological entity, such as a peptide transduction domain. Due to generally low uptake using these agents, several approaches have been described to optimize the internalization process [20,22], including linking nanoparticles to the highly cationic HIV-tat peptide $[23,24]$ or the use of an anti-transferrin receptor monoclonal antibody covalently linked to nanoparticles [25].

\section{Cardiovascular animal cell tracking studies using intracellular MRI contrast agents}

MRI Tracking of cells labeled with iron-oxide based nanoparticles, in cardiovascular disease has been utilized in a variety of animal studies. An overview of these studies can be found in Table 3 .

In one study rats were subjected to MI and subsequent intramyocardial injection of SPIO labeled allogeneic MSCs [26]. The MSCs were injected in the border zone of the infarct area. Hypointense regions were visible on MRI in the entire 16 week follow-up period. In non-MI control rats injected with labeled cells, the hypointense regions were only visible on MRI for 1 week. This was also the case for MI control rats receiving SPIO particles alone. This indicated that cell retention is dependent on the presence of inflammation in the target tissue and also that SPIO particles from dead cells will be cleared from the area and therefore the hypointense regions on MRI corresponded to SPIO particles within live cells. This was confirmed in histologic analysis done after 1, 16 and 20 weeks. SPIO containing cells were identified at the injection site. Macrophage specific CD68 staining was done and showed that macrophages were only present after 1 week and not after 16 and 20 weeks. The majority of CD68 positive cells did not contain iron, and most of the iron containing cells did not express CD68. Thus, the originally labeled cells were present and not within macrophages. In another study, mice with MI received intramyocardial injections of SPIO labeled allogeneic cardiac embryonic stem cells in the border zone of the infarction [27]. Hypointense areas were visible at the injection sites for the entire follow-up period of 4 weeks and post mortem histology confirmed that labeled cells were present in the ischemic region after 4 weeks. 
Table 3. Cardiovascular animal cell tracking studies with MRI.

\begin{tabular}{llll}
\hline Study & $\begin{array}{l}\text { Species Cell type Agent Delivery Results } \\
(\mathrm{n})\end{array}$ \\
\hline
\end{tabular}

\section{Small animals}

Stuckey et Rats

al.

2006 [26]
(18) MSC

Allogeneic SPIO SC

Direct Intra- Detection of transplanted labeled cells up to 16 weeks in MI rats. Only for 1 week myocardial into in non-MI rats.

infarct border Histology identified SPIO containing cells at the injection sites. CD68 staining

zone showed that macrophages were present after 1 week, but not after 16 weeks or 20 weeks. CD68 positive cells did not contain iron, and iron containing cells did not express CD68.

Amsalem Rats Allogeneic SPIO Direct Intra- Hypointense areas at injection sites visible after 4 weeks.

2007 [28]

$\begin{array}{lll}\text { Ebert et al. } & \text { Mice } & \text { Allogeneic SPIO } \\ 2007[27] & (16) & \text { CESC }\end{array}$ infarct area infiltrated with inflammatory cells and that most MSC did not survive.

Direct Intra- Detection of transplanted cells up to 4 weeks.

myocardial into Labeled cells were still present in the ischemic region after 4 weeks.

infarct border

zone

Terrovitis Rats Allogeneic SPIO Direct Intra- Detection of transplanted cells up to 3 weeks.

et al.

(21) and

Xeno-geneic

$\mathrm{CDC}$

myocardial into PB and CD68 stain showed injection sites with iron containing macrophages and infarct area or only few of the injected cells.

normal myo-

cardium

Chapon et

al.

Allogeneic

USPIO Direct Intra-

Detection of transplanted cells up to 6 weeks.

2009 [30]

(15) MSC

myocardial into PB stain and fluorescence microscopy showed the presence of the labeled cells at infarct area and the injections sites after 6 weeks.

border zone At 8 days neither the dead cells nor their iron content were detected. The injected labeled cells had no influence on the function of healthy myocardium

Larger animals

Bulte et al. Canine Autologous SPIO

2005 [31] (6)

Kraitchman Swine Autologous SPIO

et al. (5) MSC

$2003[36]$

Armado et Swine Allogeneic SPIO Percutaneous Detection of transplanted cells up to 8 weeks.

al. (14) MSC Intramyocardial Labeled cells were still present in the ischemic region after 8 weeks.

2005 [37]

Ma et al. Swine Autologous SPIO Intracoronary

2011 [35]

(20) MSC /

USPIO

Intramyocardial Hypointense areas at injection sites visible after 8 weeks.

into infarct $\quad$ PB stain showed presence of SPIO containing cells well integrated within the border zone tissue.

Intramyocardial Detection of transplanted cells up to 3 weeks.

PB stain was positive for iron in sections corresponding to the injection sites. Fluorescently labeling indicated that SPIO remained within the originally labeled cells.

Peng et al. Swine Autologous SPIO Intracoronary $2011[34] \quad$ (20) MSC

Yang et al. Swine Autologous SPIO Intracoronary 2011 [32] (25) MSC

Graham et Swine Autologous SPIO Intracoronary

al. (11) EPC

$2010[33]$

Detection of transplanted USPIO labeled cells after 8 weeks. SPIO labeled cells after 4-8 weeks.

$\mathrm{PB}$ stain and fluorescence microscopy showed the originally SPIO and USPIO labeled MSCs corresponding to the MRI signals.

Detection of transplanted cells after 3 weeks. PB stain and fluorescence microscopy after 8 weeks showed the presence of the originally labeled cells in the border zone of the infarction but not in the infarct zone.

Detection of transplanted cells after 8 weeks. PB stain showed SPIO containing cells in both the border zone and the infarct zone, with most found in the border zone. Fluorescence microscopy showed that the SPIO particles were inside the originally labeled cells. CD68 stain showed that the cells were not taken up by monocytes or macrophages.

Detection of transplanted cells after 6 weeks.

Staining with MAC387 showed sparse macrophages, which were separate from the cells containing SPIO particles. Analysis of cell surface markers demonstrated that the labeled cells expressed the same markers as the original transplanted cells.

MSC: mesenchymal stromal cells; SPIO: super-paramagnetic iron oxide; MI: myocardial infarction; PB: Prussian Blue; CESC: Cardiac Embryonic Stem Cells;

CDC cardiac derived stem cells; USPIO: ultra-small super-paramagnetic iron oxide; MRI: magnetic resonance imaging; EPC: endothelial progenitor cells. 
Interesting results were found in a study using a rat MI model, where SPIO labeled allogeneic MSCs were injected intramyocardially into the infarct area 7 days post MI [28]. Hypointense regions were visible on MRI in the entire follow-up period of 4 weeks. Post mortem tissue staining with Prussian Blue (PB) revealed that the delivery sites for both labeled and non-labeled cells were infiltrated with inflammatory cells and that most MSCs did not survive. Similar histologic findings where iron particles were engulfed in macrophages, was found in another rat MI study, where rats received intramyocardial injections of either xenogeneic human CDCs or allogeneic rat CDCs [29]. The findings in these two studies are in contrast with the other studies mentioned. In the study by Amsalem et al. [28] the labeled cells were injected directly into the scar area, whereas most other studies have injected cells into the border zone of infarction. Perhaps the alternative injection site could explain the diverse results in this study. In the study by Terrovitis et al. [29] labeled cells was also injected into the scar area, but also into healthy myocardium. These findings could also be due to alternative injection sites, as poor retention in healthy myocardium was also found in the study mentioned above by Stuckey et al. [26]. Moreover, CDCs were used in the study by Terrovitis et al., which are not immunoprivileged like the MSCs used in most other studies [29].

USPIO labeled allogeneic MSCs were injected intramyocardially into both the lesion and the border zone of the myocardial infarction in yet another rat study [30]. Hypointense areas were visible on MRI after 6 weeks and PB stain and fluorescence microscopy showed the presence of the labeled cells at the injections sites. In histology of control rats injected with dead cells, neither the dead cells nor their iron content were detected after 8 days. Using a canine MI model, SPIO labeled autologous MSCs were injected intramyocardially into the border zone of infarction 3 days post MI [31]. Injection sites were visible on MRI as hypo-intense regions for the entire 8 week follow-up period. Histology with PB stain showed presence of SPIO containing cells well integrated within the tissue.

Intracoronary infusion was used in a porcine MI model where SPIO labeled autologous MSCs were infused 1-2 weeks post MI [32]. Hypointense areas were visible on MRI after 8 weeks. PB staining showed SPIO containing cells in both the border zone and the infarct zone, with most found in the border zone. Fluorescence microscopy showed that the SPIO particles were inside the originally labeled cells. CD68 staining showed that the cells were not taken up by monocytes or macrophages. Corresponding findings were reported by a similar porcine study also using intracoronary infusion of SPIO labeled autologous MSCs 1 week post MI [33]. Hypointense areas were again visible the entire follow-up period of 6 weeks and post mortem staining with anti-macrophage antibody (MAC387) showed sparse macrophages, which were separate from the cells containing SPIO particles. Analysis of cell surface markers demonstrated that the labeled cells expressed the same markers as the original transplanted cells. Peng et al. confirmed these results in another similar porcine study, where SPIO labeled autologous MSCs were delivered by intracoronary infusion 1 week after MI [34]. Hypointense areas were visible on MRI after a 3 week MRI follow-up period. PB stain and fluorescence microscopy after 8 weeks showed the presence of the originally labeled cells in the border zone of the infarction, but not in the infarct zone.

$\mathrm{Ma}$ et al. compared intracoronary infusion of SPIO and USPIO labeled autologous MSCs after MI [35]. USPIO labeled cells were detected as hypointense areas on MRI for 8 weeks, whereas SPIO labeled cells were detected for 4-8 weeks. PB stain and fluorescence microscopy showed the originally SPIO and USPIO labeled MSCs corresponding to hypointense signals. Intramyocardial injection of SPIO labeled autologous MSCs were used in another study on pigs after MI [36]. In this study MRI was performed up to 3 weeks after treatment and hypointense areas were visible throughout this period. PB stain was positive for iron in sections corresponding to the injection sites. In addition, fluorescence labeling indicated that SPIO particles remained within the originally labeled cells. Finally SPIO labeled allogeneic MSC were injected intramyocardially in pigs 3 days post MI in another study [37]. MRI signals were detected for 8 weeks and histologic analyses showed that labeled cells were still present in the ischemic region.

\section{Clinical cell tracking studies using intracellular MRI contrast agents}

MRI tracking of iron-oxide based nanoparticles labeled cells have yet to be carried out in a clinical cardiovascular setting, but both SPIO and USPIO have been used successfully in different clinical studies.

In one study, 10 patients with spinal cord injury received spinal injections of autologous CD34+ cells labeled with magnetic beads [38]. Treatment was safe and the labeled cells were tracked with MRI as hypo-intense signals in five patients up to 35 days after injection. In another study, SPIO labeled autologous dendritic cells were injected in lymph nodes in 11 
melanoma patients [39]. The treatment was safe and labeled cells could be tracked on MRI. Histology of resected lymph nodes confirmed the presence of the original labeled cells. The SPIO labeled cells were negative for the macrophage marker CD68, indicating that the SPIO positive cells were not macrophages. SPIO labeled cells were also used in 15 patients with multiple sclerosis and 19 patients with amyotrophic lateral sclerosis [40]. Patients received spinal injections of SPIO labeled MSCs. Treatment was safe and the labeled MSCs were visualized as hypo-intense signals with MRI. SPIO labeled pancreatic islets were transplanted into the livers of 4 patients with type 1 diabetes [41]. Treatment was safe and labeled islets were identified as hypo-intense spots in 3 of 4 patients with MRI. In yet another study, one patient with brain trauma was transplanted with SPIO labeled neural cells [42]. Treatment was safe and the labeled cells were tracked for 3 weeks. USPIO particles have been used with success in clinical settings as an MRI contrast in patients with stroke [43] and for sentinel node identification in cancer patients [44,45].

\section{Cardiovascular cell tracking with reporter genes}

Reporter genes are DNA sequences that are introduced to genome of the cell type of interest. The reporter genes encode reporter proteins which in turn can form a complex via specific binding to a selected radiotracer (e.g. reporter probe), which can then be traced by PET, SPECT or MRI. The reporter gene can be introduced to the cells by a variety of methods, including transfection of plasmid DNA, transduction with viral vectors, or incorporation into the DNA of genetically engineered animals [46]. Reporter genes have the advantage that the signal emitted is based on the viability and biology of the cell. As the reporter genes are stably integrated into the host cell genome, the reporter will not be lost or diluted upon cell division [47]. Reporter genes are therefore suited for long term tracking of cells after implantation.

In vitro studies have demonstrated that embryonic stem cells can be stably transduced with a reporter gene without affecting cell viability, proliferation or differentiation capacity and animal studies demonstrated the possibility to monitor survival, proliferation and migration of injected cells $[48,49]$. The most widely used reporter gene for radiotracer based imaging is herpes simplex virus type 1 thymidine kinase (HSV1-tk). The intracellular complex formed by this enzyme and the reporter probe can then be imaged by PET or SPECT. Several other alternative reporter genes for PET and/or SPECT are also available.
Recently, there has been focus on developing reporter genes for MRI. Candidates have mostly been intracellular metalloproteins like ferritin and tyrosinase. These metalloproteins accumulate intracellular iron and thereby a paramagnetic effect can be detected on MRI. In contrast to PET and SPECT reporter genes, MRI reporter genes do not require reporter probes to 'turn-on' the label, as the accumulation of intracellular iron will bring them in a state of 'always on'.

\section{Cardiovascular animal cell tracking studies using reporter genes}

An overview of cardiovascular reporter gene studies is presented in Table 4.

$\mathrm{Wu}$ et al. injected allogeneic rat cardiomyoblasts transfected with a mutant of the HSV1-tk reporter gene, using a replication-defective recombinant adenovirus, into the myocardium of healthy rats [50]. With an ${ }^{18} \mathrm{~F}$ based reporter probe is was possible to follow the implanted cells for up to 2 weeks. This study was the first to demonstrate the feasibility of PET reporter genes. In another study of healthy rats, Cao et al injected allogeneic embryonic stem cells transfected with a triple fusion reporter gene, enabling simultaneous PET, bioluminescence and fluorescence imaging [51]. The study reported survival and proliferation, through increasing signal up to 4 weeks, of the implanted cells.

Sodium iodide symporter (NIS) was used as reporter gene in a study, where rats received intramyocardial injections with allogeneic CDCs transfected with NIS after MI [52]. NIS can be used for both SPECT and PET reporter probes. ${ }^{99 \mathrm{mTC}}$ was used as SPECT probe and implanted cells could be visualized by SPECT up to 6 days post-injection. NIS expression in CDCs did not affect cell viability and proliferation. True long term tracking was reported by Wang et al., who injected human CD34+ cells transfected with the HSV1-tk reporter gene into the border zone of infarction in mice after MI [53]. An ${ }^{18} \mathrm{~F}$ based reporter probe was also used here. A combination of bioluminescence and PET imaging showed that injected CD34+ cells survived in the hearts for longer than 12 months in the wall of the left ventricle.

Autologous MSCs labeled with another triple fusion reporter gene was injected percutaneously in the infarct border zone in swine 2 weeks post MI [54]. PET scan 7 days after showed a decreased cardiac uptake of the ${ }^{18} \mathrm{~F}$ based reporter probe. After 10 days, presence of the reporter gene labeled MSCs (5.8\% of the injected cells) in the myocardium was confirmed histologically. This study was the first cell tracking study using reporter genes in larger animals. 
Table 4. Cardiovascular animal cell tracking studies with reporter genes.

\begin{tabular}{|c|c|c|c|c|c|c|}
\hline Study & $\begin{array}{l}\text { Species } \\
(\mathrm{n})\end{array}$ & Cell type & $\begin{array}{l}\text { Reporter } \\
\text { gene }\end{array}$ & $\begin{array}{l}\text { Reporter } \\
\text { Probe }\end{array}$ & Delivery & Results \\
\hline \multicolumn{7}{|c|}{ Small animals } \\
\hline $\begin{array}{l}\text { Wu et al. } \\
2003[50]\end{array}$ & Rats (25) & $\begin{array}{l}\text { Allogeneic } \\
\text { cardio } \\
\text {-myoblasts }\end{array}$ & $\begin{array}{l}\text { HSV1-sr } \\
39 \text { tk }\end{array}$ & $\begin{array}{l}\text { 18F-FHBG } \\
(\mathrm{PET})\end{array}$ & $\begin{array}{l}\text { intramyocardial } \\
\text { injection }\end{array}$ & $\begin{array}{l}\text { At day } 2 \text { PET revealed that within the transplanted region, } \\
\text { there was a } 4.5 \text { fold increase of in vivo }{ }^{18} \mathrm{~F}-\mathrm{FHBG} \text { activity } \\
\text { compared with control animals. }\end{array}$ \\
\hline $\begin{array}{l}\text { Cao et al. } \\
2006[51]\end{array}$ & Rats (26) & Allogeneic ESC & TF1 & $\begin{array}{l}{ }^{18} \mathrm{~F}-\mathrm{FHBG} \\
(\mathrm{PET})\end{array}$ & $\begin{array}{l}\text { intramyocardial } \\
\text { injection }\end{array}$ & $\begin{array}{l}\text { Bioluminescence and PET signals demonstrated survival } \\
\text { and proliferation of ESCs up to } 4 \text { weeks after implantation. }\end{array}$ \\
\hline $\begin{array}{l}\text { Terrovitis } \\
\text { et al. } \\
2008[52]\end{array}$ & Rats (31) & $\begin{array}{l}\text { Allogeneic } \\
\text { CDC }\end{array}$ & NIS & $\begin{array}{l}{ }^{99 \mathrm{mTc}} \\
(\mathrm{SPECT})\end{array}$ & $\begin{array}{l}\text { intramyocardial } \\
\text { injection }\end{array}$ & $\begin{array}{l}\text { Cells could be visualized by SPECT up to } 6 \text { days } \\
\text { post-injection. } \\
\text { NIS expression in CDCs did not affect cell viability and } \\
\text { proliferation. }\end{array}$ \\
\hline $\begin{array}{l}\text { Wang et } \\
\text { al. } \\
2010[53]\end{array}$ & Mice (14) & $\begin{array}{l}\text { Xenogeneic } \\
\text { CD34+ cells }\end{array}$ & HSV1-tk & $\begin{array}{l}\text { 18F-FEAU } \\
(\mathrm{PET})\end{array}$ & $\begin{array}{l}\text { intramyocardial } \\
\text { into infarct } \\
\text { border zone }\end{array}$ & $\begin{array}{l}\text { Bioluminescence imaging showed that injected CD } 34+\text { cells } \\
\text { survived in the hearts for longer than } 12 \text { months. } \\
\text { The PET signal from the injected cells was detected in the } \\
\text { wall of the left ventricle. }\end{array}$ \\
\hline $\begin{array}{l}\text { Naumova } \\
\text { et al. } \\
2008[55]\end{array}$ & Mice (16) & $\begin{array}{l}\text { Allogeneic } \\
\text { skeletal } \\
\text { myoblasts }\end{array}$ & $\begin{array}{l}\text { HA-ferri } \\
\text { tin } \\
\text { cDNA }\end{array}$ & (MRI) & $\begin{array}{l}\text { intramyocardial } \\
\text { into infarct } \\
\text { border zone }\end{array}$ & $\begin{array}{l}\text { The transgenic grafts were detected in-vivo } 3 \text { weeks after } \\
\text { transplantation on MRI as hypointense areas caused by } \\
\text { iron accumulation in the overexpressed ferritin complexes. } \\
\text { Ferritin overexpression did not interfere with cell viability, } \\
\text { proliferation, or differentiation capacity. }\end{array}$ \\
\hline \multicolumn{7}{|c|}{ Larger animals } \\
\hline $\begin{array}{l}\text { Gyöngyösi } \\
\text { et al. } \\
2008[54]\end{array}$ & $\begin{array}{l}\text { Swine } \\
(14)\end{array}$ & $\begin{array}{l}\text { Autologous } \\
\text { MSC }\end{array}$ & TF2 & $\begin{array}{l}{ }^{18} \mathrm{~F}-\mathrm{FHBG} \\
(\mathrm{PET})\end{array}$ & $\begin{array}{l}\text { Percutaneous } \\
\text { intramyocardial } \\
\text { into infarct } \\
\text { border zone }\end{array}$ & $\begin{array}{l}\text { Seven days after injections, PET showed a decreased car- } \\
\text { diac uptake of }{ }^{18} \text { F-FHBG. } \\
\text { After } 10 \text { days, presence of the reporter gene labeled MSCs } \\
\text { ( } 5.8 \% \text { of the injected cells) in the myocardium was con- } \\
\text { firmed histologically. }\end{array}$ \\
\hline . & 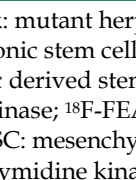 & $1+T_{1}$ & 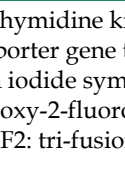 & 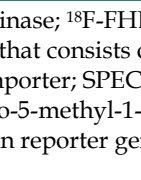 & (1) if & $\begin{array}{l}\text { oxymethylbutyl) guanine; PET: Positron emission tomography; } \\
\text { omeric red fluorescence protein; and truncated thymidine kinase; } \\
\text { n computed tomography; HSV1-tk: herpes simplex virus type } 1 \\
\text { acil; HA: influenza hemagglutinin; MRI: magnetic resonance }\end{array}$ \\
\hline
\end{tabular}

An MRI reporter gene was used in a study by Naumova and colleges [55]. In this study a ferritin-overexpressing gene (murine ferritin cDNA with an influenza hemagglutinin epitope tag) was transfected into murine skeletal myoblasts and the cells where then injected intramyocardially into the infarct border zone after MI. The transgenic grafts were detected in-vivo 3 weeks after transplantation on MRI as hypointense areas caused by iron accumulation in the overexpressed ferritin complexes. Ferritin overexpression did not interfere with cell viability, proliferation, or differentiation capacity.

\section{Clinical human cell tracking studies using re- porter genes}

Cell tracking using reporter genes in a cardiovascular setting have yet to be carried out. However, a clinical cell tracking study using reporter genes has been done successfully in a patient with a recurrent brain tumor [56]. In this study autologous cytolytic CD8+ T-cells were transfected with both a reporter gene (HSV1-tk) and therapeutic gene, encoding a re- ceptor protein that targets tumor cells and injected into the resection cavity of the original tumor, adjacent to the new tumor. With ${ }^{18}$ F-FHBG as reporter probe it was possible to track the labeled T-cells in the tumor.

\section{Discussion}

Originally, it was believed that cell therapy after MI had a direct regenerative effect in the heart [57]. Presently, most research indicates that that the improvements are achieved through a paracrine effect [58]. It is likely that the ratio of direct/paracrine effect depends, among other biological variables, on the cell type used and the conditions of the host tissue. Regardless, whether through a direct regenerative effect or a paracrine effect, the presence (even if brief) of transplanted cells in the damaged myocardium appears to be an important factor.

There are still many unanswered questions about the ideal cell type for different patient populations in addition to timing, dose and optimal delivery 
route. To clarify these factors and to optimize the beneficial effect of cell therapies, it is important to be able to non-invasively monitor the presence of transplanted cells and the kinetics and biology of transplanted cells over time and to integrate this with the clinical effects seen in patients.

\section{Radionuclides}

Cell tracking using direct radionuclide labeling and PET and SPECT imaging provides high sensitivity in visualization of implanted cells, but poor spatial resolution and the short half-lives of the used radioisotopes limits this imaging modality, which is presently most suited for short term tracking of cell therapies. Hybrid imaging modalities like SPECT/CT or PET/MR imaging may be another way to overcome some of the problems with short term radionuclide labeling cell tracking studies [9].

The short term cell tracking studies that have been done have demonstrated several interesting results. For instance, it should now be obvious that intravenous infusion is not the optimal route for cardiovascular cell therapy since the vast majority of cell home outside the heart $[4,11,14]$.

Some of the animal studies indicated that there was a significant leak of radioactivity from the cells into surrounding tissue after transplantation. This would potentially confound the quantification and positive identification of the labeled cells. Tran et al. found a method for correcting the imaging results for this phenomenon [6]. The radioactivity levels should be kept to a minimum, due to the concern of inherent radiation damage to the cells and the host. Therefore the radioactive leaking from labeled cell is an important issue, and it should be followed up in future studies.

Several studies have shown impaired viability and proliferation capacity 48-72 hours after labeling stem cells with ${ }^{111}$ In-oxine and ${ }^{111}$ In-tropolone $[5,59,60]$. In contrast, other studies have reported nucleotide labeling not affecting viability, proliferation, or migratory capacity of implanted cells $[4,6]$. Different cell types have been used in these studies and impaired viability and proliferation capacity may be a cell type problem. The issue should be explored further into in future studies using these radionuclides.

\section{MRI}

MRI of implanted cells labeled with super paramagnetic iron particles has potential for both short term and relative long term cell tracking. MRI offers high image resolution and excellent soft-tissue contrast.

A limitation of this method is that the MRI hypo intensities depend on the presence of iron particles in the field of view and not if the particles are actually still within the original labeled cells. This has been a major concern with this imaging method. A few rat studies have observed that the area with implanted cells was infiltrated with inflammatory cells and that most of the implanted cells did not survive after implantation $[28,29]$. None of the other animal studies observed this phenomenon, and most other studies that have made explicit histologic analyses of this issue have found the opposing results, namely that the labeled cells were still alive within the target tissue and not infiltrated by macrophages or monocytes $[26,27,30-37]$. In both studies where the area of implanted cells was infiltrated with macrophages, the cells were injected directly into to infarct lesion, whereas most other studies have injected their cells into the border zone of the infarct zone. This alternative injection site could be the explanation for the phenomenon. Overall, the concern for phagocytic engulfment of injected cells seems overrated and should not hinder future studies in this area.

In most of the super paramagnetic cell tracking studies the implanted cells were visible as hypo intense areas on MRI in the entire follow-up period, with for the longest of the studies was 16 weeks [26]. It should be noted that most studies observed a gradual loss of the MRI intensity during the follow up period, which is to be expected as cell divisions and cell migration will dilute the contrast. But how long super paramagnetic iron oxide labeled cells can actually be followed on MRI is still undetermined.

A significant clinical problem common to all MRI methods is the contraindication of scanning when implantable devices, such pacemakers or defibrillators, or prosthesis are present. However, due to its safety profile and non-invasive property MRI represents, so far, the major imaging method of tracking stem cells in vivo [61].

\section{Reporter Genes}

Cell tracking using reporter genes for is a highly interesting method that holds much promise. The results from animal studies have been encouraging and we have for example recently seen evidence that implanted cells can survive in the heart after implantation for more than 12 months [53].

Currently reporter gene technology is mostly used in animals, due to safety and ethical concerns about the required genetic modification and whether this may alter the cell function. Although there are risks of mutagenesis, the risk may be low $[62,63]$. Novel developments in site-specific integration technology may even circumvent this issue [64]. 
As in other methods with radioisotope tracing with PET or SPECT, there is also the issue of exposure to ionizing radiation. With MRI reporter genes, this is not an issue.

\section{Future perspectives}

Currently the field of non-invasive cell tracking imaging is being researched intensively. Isotopes with longer half-life such as ${ }^{64} \mathrm{Cu}$ (12.7 hours) could prolong the tracking period for imaging of direct radionuclide labeled cells $[65,66]$. In the field of MRI tracking of stem cells, future clinical cardiovascular studies will hopefully soon take advantage of this promising imaging modality. Where traditional MRI relies on the density and magnetic environment of hydrogen atoms, a new concept of non-proton MRI for cell tracking for quantitative, longitudinal cell tracking is under development [67-69]. The use of a tracer based on ${ }^{19} \mathrm{~F}$, instead of metal-based contrast agents such as iron oxides, allows for quantification of cell numbers directly from the image data. Unfortunately, its poor sensitivity requires further evaluation before it is assessed for widespread use. While use of reporter genes for cell tracking might still be in its infancy, many new reporter genes are being developed and if the safety and ethical concerns can be eliminated, this method is very promising.

\section{Conclusion}

All of the described imaging modalities have limitations. Therefore, combining imaging modalities may be useful for the best characterization of cardiovascular cell therapy. The most effective imaging strategy must be determined in each case, considering the need for high spatial resolution, sensitivity or follow up time.

\section{Competing Interests}

The authors have declared that no competing interest exists.

\section{References}

1. Yusuf S, Reddy S, Ounpuu S, Anand S. Global burden of cardiovascular diseases: part I: general considerations, the epidemiologic transition, risk factors, and impact of urbanization. Circulation. 2001; 104: 2746-2753.

2. Yusuf S, Reddy S, Ounpuu S, Anand S. Global burden of cardiovascular diseases: Part II: variations in cardiovascular disease by specific ethnic groups and geographic regions and prevention strategies. Circulation. 2001; 104: 2855-2864

3. Mathiasen $\mathrm{AB}$, Haack-Sorensen M, Kastrup J. Mesenchymal stromal cells for cardiovascular repair: current status and future challenges. Future Cardiol. 2009; 5: 605-617.

4. Aicher A, Brenner W, Zuhayra M, Badorff C, Massoudi S, Assmus B, Eckey T, Henze E, Zeiher AM, Dimmeler S. Assessment of the tissue distribution of transplanted human endothelial progenitor cells by radioactive labeling. Circulation. 2003: 107: 2134-2139.

5. Brenner W, Aicher A, Eckey T, Massoudi S, Zuhayra M, Koehl U, Heeschen C, Kampen WU, Zeiher AM, Dimmeler S, Henze E. 111In-labeled CD34+ hematopoietic progenitor cells in a rat myocardial infarction model. J Nucl Med. 2004; 45: 512-518.
6. Tran N, Li Y, Maskali F, Antunes L, Maureira P, Laurens MH, Marie PY, Karcher G, Groubatch F, Stoltz JF, Villemot JP. Short-term heart retention and distribution of intramyocardial delivered mesenchymal cells within necrotic or intact myocardium. Cell Transplant. 2006; 15: 351-358.

7. Terrovitis J, Lautamaki R, Bonios M, Fox J, Engles JM, Yu J, Leppo MK, Pomper MG, Wahl RL, Seidel J, Tsui BM, Bengel FM, Abraham MR, Marban E. Noninvasive quantification and optimization of acute cell retention by in vivo positron emission tomography after intramyocardial cardiac-derived stem cell delivery. J Am Coll Cardiol. 2009; 54: 1619-1626.

8. Mitchell AJ, Sabondjian E, Sykes J, Deans L, Zhu W, Lu X, Feng Q, Prato FS, Wisenberg G. Comparison of initial cell retention and clearance kinetics after subendocardial or subepicardial injections of endothelial progenitor cells in a canine myocardial infarction model. J Nucl Med. 2010; 51: 413-417.

9. Sabondjian E, Mitchell AJ, Wisenberg G, White J, Blackwood KJ, Sykes I, Deans L, Stodilka RZ, Prato FS. Hybrid SPECT/cardiac-gated first-pass perfusion CT: locating transplanted cells relative to infarcted myocardial targets. Contrast Media Mol Imaging. 2012; 7: 76-84.

10. Hou D, Youssef EA, Brinton TJ, Zhang P, Rogers P, Price ET, Yeung AC, Johnstone BH, Yock PG, March KL. Radiolabeled cell distribution after intramyocardial, intracoronary, and interstitial retrograde coronary venous delivery: implications for current clinical trials. Circulation. 2005; 112: I150-I156.

11. Hofmann M, Wollert KC, Meyer GP, Menke A, Arseniev L, Hertenstein B, Ganser A, Knapp WH, Drexler H. Monitoring of bone marrow cell homing into the infarcted human myocardium. Circulation. 2005; 111: 2198-2202.

12. Blocklet D, Toungouz M, Berkenboom G, Lambermont M, Unger P, Preumont N, Stoupel E, Egrise D, Degaute JP, Goldman M, Goldman S. Myocardial homing of nonmobilized peripheral-blood CD34+ cells after intracoronary injection. Stem Cells. 2006; 24: 333-336.

13. Goussetis E, Manginas A, Koutelou M, Peristeri I, Theodosaki M, Kollaros N, Leontiadis E, Theodorakos A, Paterakis G, Karatasakis G, Cokkinos DV, Graphakos S. Intracoronary infusion of CD133+ and CD133-CD34+ selected autologous bone marrow progenitor cells in patients with chronic ischemic cardiomyopathy: cell isolation, adherence to the infarcted area, and body distribution. Stem Cells. 2006; 24: 2279-2283.

14. Kang WJ, Kang HJ, Kim HS, Chung JK, Lee MC, Lee DS. Tissue distribution of 18F-FDG-labeled peripheral hematopoietic stem cells after intracoronary administration in patients with myocardial infarction. J Nucl Med. 2006; 47: 1295-1301.

15. Penicka M, Lang O, Widimsky P, Kobylka P, Kozak T, Vanek T, Dvorak J, Tintera J, Bartunek J. One-day kinetics of myocardial engraftment after intracoronary injection of bone marrow mononuclear cells in patients with acute and chronic myocardial infarction. Heart. 2007; 93: 837-841.

16. Schachinger $\mathrm{V}$, Aicher A, Dobert N, Rover R, Diener J, Fichtlscherer S, Assmus B, Seeger FH, Menzel C, Brenner W, Dimmeler S, Zeiher AM. Pilot trial on determinants of progenitor cell recruitment to the infarcted human myocardium. Circulation. 2008; 118: 1425-1432.

17. Merbach A,Toth É. The Chemistry of Contrast Agents in Medical Magnetic Resonance Imaging. New York, NY, USA: John Wiley \& Sons; 2001.

18. Wunderbaldinger $\mathrm{P}$, Josephson $\mathrm{L}$, Weissleder R. Crosslinked iron oxides (CLIO): a new platform for the development of targeted MR contrast agents. Acad Radiol. 2002; 9 (Suppl 2):S304-6.

19. Babic M, Horak D, Trchova M, Jendelova P, Glogarova K, Lesny P, Herynek V, Hajek M, Sykova E. Poly(L-lysine)-modified iron oxide nanoparticles for stem cell labeling. Bioconjug Chem. 2008; 19: 740-750.

20. Bulte JW, Arbab AS, Douglas T, Frank JA. Preparation of magnetically labeled cells for cell tracking by magnetic resonance imaging. Methods Enzymol. 2004; 386:275-299.

21. Arbab AS, Yocum GT, Kalish H, Jordan EK, Anderson SA, Khakoo AY, Read EJ, Frank JA. Efficient magnetic cell labeling with protamine sulfate complexed to ferumoxides for cellular MRI. Blood. 2004; 104: 1217-1223.

22. Daldrup-Link HE, Rudelius M, Oostendorp RA, Settles M, Piontek G, Metz S, Rosenbrock H, Keller U, Heinzmann U, Rummeny EJ, Schlegel J, Link TM. Targeting of hematopoietic progenitor cells with MR contrast agents. Radiology. 2003; 228: 760-767.

23. Josephson L, Tung $\mathrm{CH}$, Moore A, Weissleder R. High-efficiency intracellular magnetic labeling with novel superparamagnetic-Tat peptide conjugates. Bioconjug Chem. 1999; 10: 186-191.

24. Mathiasen AB, Hansen L, Friis T, Thomsen C, Bhakoo K, Kastrup J. Optimal labeling dose, labeling time, and magnetic resonance imaging detection limits of ultrasmall superparamagnetic iron-oxide nanoparticle labeled mesenchymal stromal cells. Stem Cells Int. 2013; 2013: 353105

25. Bulte JW, Zhang S, van GP, Herynek V, Jordan EK, Duncan ID, Frank JA. Neurotransplantation of magnetically labeled oligodendrocyte progenitors: magnetic resonance tracking of cell migration and myelination. Proc Natl Acad Sci U S A. 1999; 96: 15256-15261.

26. Stuckey DJ, Carr CA, Martin-Rendon E, Tyler DJ, Willmott C, Cassidy PJ, Hale SJ, Schneider JE, Tatton L, Harding SE, Radda GK, Watt S, Clarke K. Iron particles for noninvasive monitoring of bone marrow stromal cell engraftment into, and isolation of viable engrafted donor cells from, the heart. Stem Cells. 2006; 24: 1968-1975. 
27. Ebert SN, Taylor DG, Nguyen HL, Kodack DP, Beyers RJ, Xu Y, Yang Z, French BA. Noninvasive tracking of cardiac embryonic stem cells in vivo using magnetic resonance imaging techniques. Stem Cells. 2007; 25: 2936-2944.

28. Amsalem Y, Mardor Y, Feinberg MS, Landa N, Miller L, Daniels D, Ocherashvilli A, Holbova R, Yosef O, Barbash IM, Leor J. Iron-oxide labeling and outcome of transplanted mesenchymal stem cells in the infarcted myocardium. Circulation. 2007; 116: I38-I45.

29. Terrovitis J, Stuber M, Youssef A, Preece S, Leppo M, Kizana E, Schar M, Gerstenblith G, Weiss RG, Marban E, Abraham MR. Magnetic resonance imaging overestimates ferumoxide-labeled stem cell survival after transplantation in the heart. Circulation. 2008; 117: 1555-1562.

30. Chapon C, Jackson JS, Aboagye EO, Herlihy AH, Jones WA, Bhakoo KK. An in vivo multimodal imaging study using MRI and PET of stem cell transplantation after myocardial infarction in rats. Mol Imaging Biol. 2009; 11: 31-38.

31. Bulte JW, Kostura L, Mackay A, Karmarkar PV, Izbudak I, Atalar E, Fritzges D, Rodriguez ER, Young RG, Marcelino M, Pittenger MF, Kraitchman DL. Feridex-labeled mesenchymal stem cells: cellular differentiation and MR assessment in a canine myocardial infarction model. Acad Radiol. 2005; 1:2-6.

32. Yang K, Xiang P, Zhang C, Zou L, Wu X, Gao Y, Kang Z, He K, Liu J, Peng C. Magnetic Resonance Evaluation of Transplanted Mesenchymal Stem Cells After Myocardial Infarction in Swine. Can J Cardiol. 2011.

33. Graham JJ, Foltz WD, Vaags AK, Ward MR, Yang Y, Connelly KA, Vijayaraghavan R, Detsky JS, Hough MR, Stewart DI, Wright GA, Dick AJ. Long-term tracking of bone marrow progenitor cells following intracoronary injection post-myocardial infarction in swine using MRI. Am J Physiol Heart Circ Physiol. 2010; 299: H125-H133.

34. Peng C, Yang K, Xiang P, Zhang C, Zou L, Wu X, Gao Y, Kang Z, He K, Liu J, Cheng $M$, Wang J, Chen L. Effect of transplantation with autologous bone marrow stem cells on acute myocardial infarction. Int J Cardiol. 2011.

35. Ma GS, Qi CM, Liu NF, Shen CX, Chen Z, Liu XJ, Hu YP, Zhang XL, Teng GJ, Ju SH, Ma M, Tang YL. Efficiently tracking of stem cells in vivo using different kinds of superparamagnetic iron oxide in swine with myocardial infarction. Chin Med J (Engl ). 2011; 124: 1199-1204

36. Kraitchman DL, Heldman AW, Atalar E, Amado LC, Martin BJ, Pittenger MF, Hare JM, Bulte JW. In vivo magnetic resonance imaging of mesenchymal stem cells in myocardial infarction. Circulation. 2003; 107: 2290-2293.

37. Amado LC, Saliaris AP, Schuleri KH, St JM, Xie JS, Cattaneo S, Durand DJ, Fitton T, Kuang JQ, Stewart G, Lehrke S, Baumgartner WW, Martin BJ, Heldman AW, Hare JM. Cardiac repair with intramyocardial injection of allogeneic mesenchymal stem cells after myocardial infarction. Proc Natl Acad Sci U S A. 2005; 102: 11474-11479.

38. Callera F, de Melo CM. Magnetic resonance tracking of magnetically labeled autologous bone marrow CD34+ cells transplanted into the spinal cord via lumbar puncture technique in patients with chronic spinal cord injury: CD34+ cells' migration into the injured site. Stem Cells Dev. 2007; 16: 461-466.

39. de Vries IJ, Lesterhuis WJ, Barentsz JO, Verdijk P, van Krieken JH, Boerman OC, Oyen WJ, Bonenkamp JJ, Boezeman JB, Adema GJ, Bulte JW, Scheenen TW, Punt CJ, Heerschap A, Figdor CG. Magnetic resonance tracking of dendritic cells in melanoma patients for monitoring of cellular therapy. Nat Biotechnol. 2005; 23: 1407-1413.

40. Karussis D, Karageorgiou C, Vaknin-Dembinsky A, Gowda-Kurkalli B, Gomori JM, Kassis I, Bulte JW, Petrou P, Ben-Hur T, Abramsky O, Slavin S. Safety and immunological effects of mesenchymal stem cell transplantation in patients with multiple sclerosis and amyotrophic lateral sclerosis. Arch Neurol. 2010; 67: 1187-1194

41. Toso C, Vallee JP, Morel P, Ris F, Demuylder-Mischler S, Lepetit-Coiffe M, Marangon N, Saudek F, James Shapiro AM, Bosco D, Berney T. Clinical magnetic resonance imaging of pancreatic islet grafts after iron nanoparticle labeling. Am J Transplant. 2008; 8: 701-706.

42. Zhu J, Zhou L, XingWu F. Tracking neural stem cells in patients with brain trauma. N Engl J Med. 2006; 355: 2376-2378.

43. Nighoghossian N, Wiart M, Cakmak S, Berthezene Y, Derex L, Cho TH, Nemoz C, Chapuis F, Tisserand GL, Pialat JB, Trouillas P, Froment JC, Hermier M. Inflammatory response after ischemic stroke: a USPIO-enhanced MRI study in patients. Stroke. 2007; 38: 303-307.

44. Dinniwell R, Chan P, Czarnota G, Haider MA, Jhaveri K, Jewett M, Fyles A, Jaffray D, Milosevic M. Pelvic lymph node topography for radiotherapy treatment planning from ferumoxtran-10 contrast-enhanced magnetic resonance imaging. Int J Radiat Oncol Biol Phys. 2009; 74(3): 844-851.

45. Froehlich JM, Triantafyllou M, Fleischmann A, Vermathen P, Thalmann GN, Thoeny HC. Does quantification of USPIO uptake-related signal loss allow differentiation of benign and malignant normal-sized pelvic lymph nodes? Contrast Media Mol Imaging. 2012; 7(3): 346-355

46. Sharma V, Luker GD, Piwnica-Worms D. Molecular imaging of gene expression and protein function in vivo with PET and SPECT. J Magn Reson Imaging. 2002; 16: 336-351.

47. Kay MA, Glorioso JC, Naldini L. Viral vectors for gene therapy: the art of turning infectious agents into vehicles of therapeutics. Nat Med. 2001; 7: 33-40.

48. Cao F, Lin S, Xie X, Ray P, Patel M, Zhang X, Drukker M, Dylla SJ, Connolly AJ, Chen X, Weissman IL, Gambhir SS, Wu JC. In vivo visualization of embryonic stem cell survival, proliferation, and migration after cardiac delivery. Circulation. 2006; 113: 1005-1014
49. Gruber PJ, Li Z, Li H, Worrad D, Huang B, Abdullah I, Wang W, El-Deiry W, Ferrari VA, Zhou R. In vivo imaging of MLC2v-luciferase, a cardiac-specific reporter gene expression in mice. Acad Radiol. 2004; 11: 1022-1028.

50. Wu JC, Chen IY, Sundaresan G, Min JJ, De A, Qiao JH, Fishbein MC, Gambhir SS. Molecular imaging of cardiac cell transplantation in living animals using optical bioluminescence and positron emission tomography. Circulation. 2003; 108: 1302-1305.

51. Cao F, Lin S, Xie X, Ray P, Patel M, Zhang X, Drukker M, Dylla SJ, Connolly AJ, Chen X, Weissman IL, Gambhir SS, Wu JC. In vivo visualization of embryonic stem cell survival, proliferation, and migration after cardiac delivery. Circulation. 2006; 113: 1005-1014.

52. Terrovitis J, Kwok KF, Lautamaki R, Engles JM, Barth AS, Kizana E, Miake J, Leppo MK, Fox J, Seidel J, Pomper M, Wahl RL, Tsui B, Bengel F, Marban E, Abraham MR. Ectopic expression of the sodium-iodide symporter enables imaging of transplanted cardiac stem cells in vivo by single-photon emission computed tomography or positron emission tomography. J Am Coll Cardiol. 2008; 52: 1652-1660.

53. Wang J, Zhang S, Rabinovich B, Bidaut L, Soghomonyan S, Alauddin MM, Bankson JA, Shpall E, Willerson JT, Gelovani JG, Yeh ET. Human CD34+ cells in experimental myocardial infarction: long-term survival, sustained functional improvement, and mechanism of action. Circ Res. 2010; 106: 1904-1911.

54. Gyongyosi M, Blanco J, Marian T, Tron L, Petnehazy O, Petrasi Z, Hemetsberger R, Rodriguez J, Font G, Pavo IJ, Kertesz I, Balkay L, Pavo N, Posa A, Emri M, Galuska L, Kraitchman DL, Wojta J, Huber K, Glogar D. Serial noninvasive in vivo positron emission tomographic tracking of percutaneously intramyocardially injected autologous porcine mesenchymal stem cells modified for transgene reporter gene expression. Circ Cardiovasc Imaging. 2008; 1: 94-103.

55. Naumova AV, Reinecke H, Yarnykh V, Deem J, Yuan C, Murry CE. Ferritin overexpression for noninvasive magnetic resonance imaging-based tracking of stem cells transplanted into the heart. Mol Imaging. 2010; 9: 201-210.

56. Yaghoubi SS, Jensen MC, Satyamurthy N, Budhiraja S, Paik D, Czernin J, Gambhir SS. Noninvasive detection of therapeutic cytolytic T cells with 18F-FHBG PET in a patient with glioma. Nat Clin Pract Oncol. 2009; 6: 53-58.

57. Orlic D, Kajstura J, Chimenti S, Jakoniuk I, Anderson SM, Li B, Pickel J, McKay R, Nadal-Ginard B, Bodine DM, Leri A, Anversa P. Bone marrow cells regenerate infarcted myocardium. Nature. 2001; 410: 701-705.

58. Gnecchi M, He H, Liang OD, Melo LG, Morello F, Mu H, Noiseux N, Zhang L, Pratt RE, Ingwall JS, Dzau VJ. Paracrine action accounts for marked protection of ischemic heart by Akt-modified mesenchymal stem cells. Nat Med. 2005; 11: 367-368.

59. Nowak B, Weber C, Schober A, Zeiffer U, Liehn EA, von HP, Reinartz P, Schaefer WM, Buell U. Indium-111 oxine labelling affects the cellular integrity of haematopoietic progenitor cells. Eur J Nucl Med Mol Imaging. 2007; 34: 715-721.

60. Yoon JK, Park BN, Shim WY, Shin JY, Lee G, Ahn YH. In vivo tracking of 111In-labeled bone marrow mesenchymal stem cells in acute brain trauma model. Nucl Med Biol. 2010; 37: 381-388.

61. Bhakoo K. In vivo stem cell tracking in neurodegenerative therapies. Expert Opin Biol Ther. 2011; 11: 911-920.

62. Wang F, Dennis JE, Awadallah A, Solchaga LA, Molter J, Kuang Y, Salem N, Lin Y, Tian H, Kolthammer JA, Kim Y, Love ZB, Gerson SL, Lee Z. Transcriptional profiling of human mesenchymal stem cells transduced with reporter genes for imaging. Physiol Genomics. 2009; 37: 23-34.

63. Wu JC, Spin JM, Cao F, Lin S, Xie X, Gheysens O, Chen IY, Sheikh AY, Robbins RC, Tsalenko A, Gambhir SS, Quertermous T. Transcriptional profiling of reporter genes used for molecular imaging of embryonic stem cell transplantation. Physiol Genomics. 2006; 25: 29-38.

64. Karow M, Chavez CL, Farruggio AP, Geisinger JM, Keravala A, Jung WE, Lan F, Wu JC, Chen-Tsai Y, Calos MP. Site-specific recombinase strategy to create induced pluripotent stem cells efficiently with plasmid DNA. Stem Cells. 2011; 29: 1696-1704.

65. Adonai N, Nguyen KN, Walsh J, Iyer M, Toyokuni T, Phelps ME, McCarthy T, McCarthy DW, Gambhir SS. Ex vivo cell labeling with 64Cu-pyruvaldehyde-bis(N4-methylthiosemicarbazone) for imaging cell trafficking in mice with positron-emission tomography. Proc Natl Acad Sci U S A. 2002; 99: 3030-3035.

66. Huang J, Lee CC, Sutcliffe JL, Cherry SR, Tarantal AF. Radiolabeling rhesus monkey CD34+ hematopoietic and mesenchymal stem cells with 64Cu-pyruvaldehyde-bis(N4-methylthiosemicarbazone) for microPET imaging. Mol Imaging. 2008; 7: 1-11.

67. Srinivas M, Morel PA, Ernst LA, Laidlaw DH, Ahrens ET. Fluorine-19 MRI for visualization and quantification of cell migration in a diabetes model. Magn Reson Med. 2007; 58: 725-734

68. Srinivas M, Boehm-Sturm P, Figdor CG, de Vries IJ, Hoehn M. Labeling cells for in vivo tracking using (19)F MRI. Biomaterials. 2012; 33: 8830-8840.

69. Boehm-Sturm P, Mengler L, Wecker S, Hoehn M, Kallur T. In vivo tracking of human neural stem cells with $19 \mathrm{~F}$ magnetic resonance imaging. PLoS One. 2011; 6:29040. 